\title{
Evaluation of antimicrobial, antioxidant and phototoxic activities of extracts and isolated compounds from Stachytarpheta cayennensis (Rich.) Vahl, Verbenaceae
}

\author{
Pierre André De Souza, ${ }^{* 1}$ Carmelita Gomes Silva, ${ }^{1}$ Barbara Rosa Pimentel Machado, ${ }^{1}$ \\ Nanci Camara de Lucas, ${ }^{1}$ Gilda Guimarães Leitão, ${ }^{2}$ Elis Cristina Araújo Eleutherio, ${ }^{3}$ \\ Gisela Maria Dellamora Ortiz, ${ }^{4}$ Leslie C Benchetrit ${ }^{5}$
}

\begin{abstract}
${ }^{1}$ Departamento de Química Orgânica, Instituto de Química, Universidade Federal do Rio de Janeiro, 21949-900 Rio de Janeiro-RJ, Brazil,

${ }^{2}$ Núcleo de Pesquisa de Produtos Naturais, Universidade Federal do Rio de Janeiro, 21941-590 Rio de Janeiro-RJ, Brazil, ${ }^{3}$ Departamento de Bioquímica, Instituto de Química, Universidade Federal do Rio de Janeiro, 21949-900 Rio de Janeiro-RJ, Brazil, ${ }^{4}$ Departamento de Medicamentos, Faculdade de Farmácia, Universidade Federal do Rio de Janeiro, 21941-900 Rio de Janeiro-RJ, Brazil,

${ }^{5}$ Departamento de Microbiologia Médica, Instituto de Microbiologia Dr. Paulo de Góes, Centro de Ciências da Saúde, Universidade Federal do Rio de Janeiro, 21941-591 Rio de Janeiro-RJ, Brazil.
\end{abstract}

\begin{abstract}
RESUMO: "Avalição da atividade antimicrobiana, antioxidante e fototóxica dos extratos e compostos isolados de Stachytarpheta cayennensis (Rich.) Vahl, Verbenaceae". Stachytarpheta cayennensis (Rich.) Vahl, Verbenaceae, é uma planta utilizada na medicina popular brasileira contra úlceras e lesões de pele. Internamente é usada contra inflamações, febre, doenças renais e aterosclerose. Essa planta foi estudada com o objetivo de identificar os compostos bioativos majoritários que possam justificar seu uso terapêutico contra lesões de pele e arteriosclerose. A atividade antioxidante do extrato bruto etanólico, partições e os compostos majoritários isolados das raízes de $S$. cayennesis foi avaliada através de testes in vivo e in vitro. In vitro a atividade antioxidante foi avaliada pelo teste fotocolorimétrico do radical 2,2-difenil-1-picrilidrazil (DPPH•). In vivo, Saccharomyces cerevisiae, um modelo de célula eucariótica, foi utilizado tanto para avaliar a fototoxicidade quanto a capacidade antioxidante contra as espécies reativas de oxigênio (EROS) menadiona e peróxido de hidrogênio. O extrato, partições e os dois compostos majoritários isolados, verbascosídeo e ácido betulínico foram capazes de aumentar a sobrevivência e diminuir a peroxidação lipídica de $S$. cerevisiae contra EROS. Verbascosídeo apresentou atividade antimicrobiana moderada contra Streptococcus pyogenes, S.epidermidis e Staphylococcus aureus. O extrato etanólico e as partições testadas não apresentaram fototoxicidade, indicando que $S$. cayennensis é uma planta segura para o tratamento de lesões de pele e como possível ingrediente em cosméticos.
\end{abstract}

Unitermos: Stachytarpheta cayennensis, antioxidante, antimicrobial, fototoxicidade, arilpropanoide glicosilado, ácido betulínico.

\begin{abstract}
Stachytarpheta cayennensis (Rich.) Vahl, Verbenaceae, plant extract, is a Brazilian medicinal plant externally used in folk medicine for purulent ulcers, skin lesions and internally for inflammations, fever, renal disorders and atherosclerosis. S. cayennesis was studied to identify potential bioactive compounds that may justify their therapeutic use against skin lesions and atherosclerosis. The antioxidant, antimicrobial and phototoxicity capacities of the crude ethanolic extract, fractions and isolated compounds from roots of S. cayennesis were evaluated through in vivo and in vitro tests. Strains of Saccharomyces cerevisiae, an eukaryotic cell model, were used to assess both the phototoxicity and the capacity to protect against the lethal oxidative stress caused by menadione and hydrogen peroxide. The extract, fractions and the two major isolated compounds, verbascoside and betulinic acid, of $S$. cayennensis were able to increase the tolerance and decrease the lipid peroxidation of $S$. cerevisiae to reactive oxygen species (ROS). The antioxidant activity was also evaluated by scavenging of 2,2-diphenyl-1-picrylhydrazyl (DPPH•). Verbascoside exhibited a moderate antimicrobial activity against Streptococcus pyogenes, S.epidermidis and Staphylococcus aureus. Neither the ethanolic extract nor fractions showed phototoxicity, indicating that the $S$. cayennensis extract is safe for use in the treatment of skin lesions and as an active cosmetic ingredient.
\end{abstract}

Keywords: Stachytarpheta cayennensis, antioxidant, antimicrobial, phototoxicity, arylpropanoid glycosides, betulinic acid. 


\section{INTRODUCTION}

Natural compounds from medicinal plants have aroused much attention, and increasing efforts have been made to search for plant-derived antioxidants and antimicrobial agents (Belinha et al., 2008; Mothana \& Lindequist, 2005). On the other hand, photosensitization caused by medicinal plants used in folk medicine, has been involved with a number of clinical skin syndromes, like dermatitis (Freitas et al., 2000; Montoya et al., 2005). The disturbances in the regulation of free radical and reactive oxygen species (ROS) processes in the organism is among the factors leading to several pathologies such as diabetes, Alzheimer, atherosclerosis, inflammatory disorders, myocardial infarction, cancer, and many others diseases (Amaral et al., 2009; Belinha et al., 2008; Parejo et al., 2003; Prior 2004).

Stachytarpheta cayennensis (Rich.) Vahl, Verbenaceae, is an herbaceous plant, popularly known as "gervão-roxo". Its leaves and roots are used in folk medicine in Brazil and other countries encompassing the Amazon rainforest to treat inflammation, varicose ulcers, fever, hepatic and renal disorders, hypertension and diabetes (Penido et al., 2006; Schapoval et al., 1998). Recently the anti-inflammatory, antinociceptive, gastroprotective and Leishmanicidal properties of ethanolic extracts were assessed (Moreira et al., 2007; Penido et al., 2006; Schapoval et al., 1998).

In the present work, the antimicrobial, antioxidant and photoxicity properties of $S$. cayennensis were investigated, despite its important ethnopharmacological uses against skin lesions, abscesses and atherosclerosis (De Souza, 2004). The crude ethanolic extract, ethyl acetate and chloroform fractions and the two major isolated compounds from these fractions, verbascoside and betulinic acid, of $S$. cayennensis were evaluated for its capacity to protect Saccharomyces cerevisiae cells, an eukaryotic cell model, against the lethal oxidative stress caused by menadione (superoxide radical generator) and hydrogen peroxide. S. cerevisiae was also used to evaluate the phototoxic effect of crude ethanolic extract and fractions. The 2.2-diphenil1-picryl-hydrazyl-hydrate $(\mathrm{DPPH} \bullet)$ free-radical assay was used as a complementary method for evaluation of antioxidant activity of $S$. cayennensis. The well-established antibacterial properties of several phenolics compounds of medicinal plants (Jimenez \& Riguera 1994; Didry et al., 1999) and the ethnopharmacological use of $S$. cayennesis prompted us to evaluate the antimicrobial activity of the ethanolic extract, fractions and the two major arylpropanoid glycosides of $S$. cayenensis against several strains of both Gram-positive and Gramnegative bacteria.

\section{MATERIAL AND METHODS}

\section{Reagents}

\section{Collection and Extraction of Plant Material}

Roots of Stachytarpheta cayennensis (Rich.) Vahl, Verbenaceae, were collected at Conceição lake, Florianópolis, Santa Catarina, Brazil. Botanical identification was done by Inês M. Oliveira da Silva from the Department of Botany at Universidade Federal Rural do Rio de Janeiro where a voucher specimen is deposited (RBR 5979). The air-dried and powdered roots (367.8 g) were placed in a Soxhlet apparatus and exhaustively extracted with $n$-hexane followed by ethanol, yielding $5 \mathrm{~g}$ and $48 \mathrm{~g}$ of crude hexane and ethanol extracts, respectively. High-speed counter-current chromatography (HSCCC) was applied to the preparative separation of the compounds verbascoside $(300 \mathrm{mg}$, isoverbascoside $(17 \mathrm{mg})$ and martynoside $(54 \mathrm{mg}$ ) from the ethyl acetate fraction and is described elsewhere (Leitão et al., $2005)$. Betulinic acid $(45.0 \mathrm{mg}$ ) was obtained from the chloroform fraction.

Menadione,1,1-diphenyl-2-picrylhydrazyl (DPPH), vanillin, 8-methoxypsoralen (8-MOP) and quercetin were obtained from Sigma Chemicals and $\mathrm{H}_{2} \mathrm{O}_{2}$ was purchased from Merck. Media components were obtained from Difco. All organic solutions used for HSCCC were of analytical grade and purchased from Tedia Brazil.

\section{Selection of two-phase solvent system by the tube partitioning test}

A small quantity of the chloroform fraction of the roots of $S$. cayennensis was dissolved in a series of test tubes containing the solvent systems $\mathrm{CH}_{2} \mathrm{Cl}_{2}: \mathrm{EtOH}: \mathrm{H}_{2} \mathrm{O}$ $(1: 1: 1,1.5: 1: 1,2: 1: 1 \mathrm{v} / \mathrm{v})$ and n-hexane: $\mathrm{CH}_{2} \mathrm{Cl}_{2}:$ EtOH: $\mathrm{H}_{2} \mathrm{O}$ $(1: 0.5: 1: 1,1: 1: 1: 1,1: 2: 1: 1 \mathrm{v} / \mathrm{v})$. The test tubes were shaken and the compounds allowed to partition between the two phases. Equal aliquots of each phase were spotted beside each other separately on silica gel TLC plates and developed with the solvent system $\mathrm{CHCl}_{3}$ :EtOAc 3:2. The results were visualized under UV light and by spraying with vanillin-sulfuric acid (1\%) solution followed by heating. The gradient solvent gradient system was defined as hexane: $\mathrm{CH}_{2} \mathrm{Cl}_{2}:$ EtOH: $\mathrm{H}_{2} \mathrm{O}(1: 1: 1: 1,1: 2: 1: 1 \mathrm{v} / \mathrm{v})$.

\section{High-Speed Countercurrent Chromatography (HSCCC) separation procedure}

The sample was prepared by dissolving $400 \mathrm{mg}$ of the chloroform fraction from $S$. cayennesis in $2.5 \mathrm{~mL}$ of each phase of the solvent system and loaded into an injection valve (Rheodyne model $5010 \mathrm{~A}$ ) equipped with a $5 \mathrm{~mL}$ loop. A P.C Inc counter-current chromatograph 
equipped with a multi-layer coil equilibrated by a counterweight was used. The $80 \mathrm{~mL}$ coil was initially filled with the stationary upper phase of the solvent system. Then, rotation started $(850 \mathrm{rpm})$ and the lower mobile phase was pumped into the coil in the head to tail $(\mathrm{H} \rightarrow \mathrm{T})$ direction at a flow rate of $2.0 \mathrm{~mL} / \mathrm{min}$ until hydrodynamic equilibrium was achieved. Under these conditions, the retention of the stationary phase $\left(\mathrm{S}_{\mathrm{F}}\right)$ in the coil was $82.5 \%(V m=14.0 \mathrm{~mL})$. CCC rotation was interrupted in tube 60 and the coil content (organic and aqueous phases) was collected ("wash-off"), giving a total of seventy fractions, of $5.0 \mathrm{~mL}$ each. All fractions obtained by CCC were analyzed by TLC using dichloromethane: acetone:methanol (2:1:0.5) as eluent. The major compound, betulinic acid, was obtained in fractions (FC 38-40) and identified by ${ }^{1} \mathrm{H}$ and ${ }^{13} \mathrm{C}$ NMR spectroscopy and the data compared with those from the literature (Mahato, 1994).

\section{Phototoxicity analysis}

Phototoxic activity of the extracts was evaluated in a microbiological assay employing a wild strain of $S$. cerevisiae carried out under previously described conditions (Freitas et al., 2000). To evaluate phototoxic activity the crude ethanolic extract from $S$. cayennensis as well as its chloroform, ethyl acetate and butanol fractions were suspended in ethanol to a final concentration of $50 \mathrm{mg} / \mathrm{mL}$. As positive control, the standard synthetic drug 8-methoxypsoralen (8-MOP) was employed, while ethanol was used as negative control of the assays. Afterwards, $10 \mu \mathrm{L}$ of samples, as well as positive and negative controls were applied in Whatman $n^{\circ} 1$ sterile paper filter discs ( $6 \mathrm{~mm}$ diameter), which were fixed on the culture plates. Control plates with test samples were kept in the dark. Culture plates were observed after $24 \mathrm{~h}$ for the presence of a clear zone of growth inhibition around the samples. The appearance of a clear zone around the sample discs after irradiation (UVA radiation 300-390 $\mathrm{nm}$ ) indicated growth inhibition and was consequently suggestive of phototoxic activity. This should be absent in culture plates maintained in the dark. Assays were made in triplicate for each sample under analysis.

\section{Antimicrobial assay and bacterial strains}

The following microorganisms were employed for determination of antimicrobial activity: Escherichia coli ATCC 25922 (American Type Culture Collection, Rockville, MD), Pseudomonas aeruginosa (ATCC 15422), Staphylococcus aureus (ATCCC 25923), Staphylococcus aureus MRSA (9393) Streptococcus pyogenes (ATCC 75194), S .epidermidis (557H9), S. saprophyticus (O-015), Salmonella typhi (ATCC 6534), Shigella sonnei, E. faecalis (ATCC 6569), S. pneumoniae
(5128), B. subtlilis (ATCC 19659), E. coli (ATCC 25922) and Groups A (75-301), B (90-356), C (75-302), D (75$335)$ and $G(08-119)$. All of the bacterial cultures were grown in nutrient broth at $36^{\circ} \mathrm{C}$ for $24 \mathrm{~h}$ and maintained in nutritive agar at $4{ }^{\circ} \mathrm{C}$ until use.

\section{Agar diffusion method and estimation of Minimal Inhibitory Concentrations (MIC)}

The study was carried out against several Grampositive and Gram-negative bacteria using the agar diffusion method to determine the antimicrobial activity described by Ellen et al. (1994). Negative controls were done using paper discs loaded with $20 \mu \mathrm{L}$ of the solvents. Positive control was Cloranfenicol at $30 \mu \mathrm{g} / \mathrm{mL}$ using only the agar diffusion method and expressed in inhibition zones $(\mathrm{mm})$ : $(S$. pyogenes $=32 \mathrm{~mm} ; S$. aureus $=25 \mathrm{~mm} ; S$. epidermidis $=23 \mathrm{~mm})$. Cotton swabs charged with each bacterial suspension $\left(10^{6} \mathrm{CFU} / \mathrm{mL}\right)$ were inoculated on plates and the bacteria were spread evenly over the surface of the agar medium. Wells of $6 \mathrm{~mm}$ diameter were aseptically cut, poured into sterile Petri Plates (15 $\mathrm{cm}$ diameter), inoculated with microbial cell suspension and were impregnated with $20 \mu \mathrm{L}$ of extract, fractions or solutions and isolated compound (equivalent to $5 \mathrm{mg}$ / disc of the dried extract) and after evaporation, the wells were placed on the surface of the inoculated agar plates. The plates were incubated at $36^{\circ} \mathrm{C}$ for $24 \mathrm{~h}$ and examined for indicator strain growth inhibition. The diameters of the inhibition zones were measured in millimeters. A positive result was defined as a zone of $9 \mathrm{~mm}$ or more in diameter of inhibited growth of bacterial strain and indicated the presence of antimicrobial activity (Mothana $\&$ Lindequist, 2005). The estimations were carried out in liquid media which contained the most active fraction. Serial two-fold dilutions of fractions were prepared in broth. Cultures containing only sterile physiological Tris buffer ( $\mathrm{pH} 7.3,0.05 \mathrm{M}$ ), which did not influence bacterial growth, were used as controls. To each test tube an equal volume of the adjusted inoculum was added. After incubation at $36^{\circ} \mathrm{C}$ for $24 \mathrm{~h}$ the MIC was read. The minimal inhibitory concentration (MIC) was defined as the lowest concentration of a fraction which was able to completely inhibit the growth of each bacterial strain (Schoenknecht et al., 1985).

\section{DPPH antioxidant analysis}

The antioxidant activity of the extract, fractions and isolated compounds from $S$. cayennensis were measured by the 2,2-diphenyl-1-picryl-hydrazyl-hydrate (DPPH) radical scavenging photometric assay according previously published papers (Parejo et al., 2003; Silva et al., 2009). Positive controls were prepared with standard solutions of Ginkgo biloba and quercetin which are known by its free radical scavenging property (Silva et al., 2009; Zhou \& Sadik, 2008). 


\section{In vivo antioxidant analysis}

This experiment was carried out by the method of Steels et al. (1994), Pereira et al. (2003) and Silva et al. (2009). The $S$. cerevisiae wild type strain BY4741 (MATa; his3; leu2; met15; ura3) used in the in vivo antioxidant assays was acquired from Euroscarf, Frankfurt, Germany. Cells were directly exposed to 2 $\mathrm{mM}$ hydrogen peroxide or $20 \mathrm{mM}$ menadione for $1 \mathrm{~h}$ at $28{ }^{\circ} \mathrm{C} / 160 \mathrm{rpm}$, or previously treated with $0.1 \mathrm{mg} / \mathrm{mL}$ of extracts (crude, ethyl acetate or chloroform extracts) or 10 $\mu \mathrm{g} / \mathrm{mL}$ of two major isolated compounds (verbascoside and betulinic acid, respectively) for $1 \mathrm{~h}$ at $28{ }^{\circ} \mathrm{C} / 160$ rpm before being stressed. To choose the doses used in the adaptive treatments, cells were exposed to increased concentrations of plant extract/isolated compounds and then spotted adjacently on YPD agar plates incorporating peroxide or menadione. The concentration chosen was the lowest that could improve cell growth compared to control exposed to stress without being treated with plant extracts/isolated compounds. Cell viability was analyzed by plating, in triplicate, on solid YPD medium, after proper dilution. Positive controls were those using the standard solutions of Ginkgo biloba and quercetin (Silva et al., 2009, Zhou \& Sadik, 2008). The results were expressed as a ratio between lipid oxidation level of stressed cells and non-stressed cells.

\section{Statistical Analysis}

Data were expressed as mean values $\pm \mathrm{SD}$ of at least three independent experiments. Values were compared by the Student's $t$-test. The latter denotes homogeneity between experimental groups at $p<0.05$.

\section{RESULTS AND DISCUSSION}

\section{Phototoxic assay}

It is necessary to analyze the phototoxicity of medicinal plants used for topical treatments (Wilhelm et al., 2001). One of the ethnopharmacological uses of $S$. cayennesis is to treat sore skin wounds applied as a plaster for abscesses (De Souza, 2004). The relatively scarce amount of published data regarding screening of phototoxic activity of plant extracts employed as infusions and cosmetics, led us to investigate the effect of an ethanolic extract from $S$. cayennensis as well as chloroformic, ethyl acetate and butanolic fractions obtained from it. Neither the ethanol extract from $S$. cayennensis nor its fractions inhibited of $S$. cerevisiae growth after irradiation under ultraviolet light and in the dark. Data is, therefore, suggestive of the absence of phototoxic activity for $S$. cayennensis or at least for its major components. Verbascoside, for example, has been shown by Avila Acevedo et al. (2005) to provide chemical defense against UV radiation by guinea pig bioassays. On the other hand, irradiation of culture plates containing the positive control 8-methoxypsoralen (8-MOP) led to a $23 \mathrm{~mm}$ diameter inhibition. Similar inhibition has also been observed for ethanol extracts from Ruta graveolens e Citrus spp in previous studies (Ramos et al., 2005). Therefore, we can conclude that the S. cayennenis are safe for topical therapies.

\section{Protection against antibacterial damage}

The ethanol extract of $S$. cayennesis showed activity by agar diffusion method only against $S$. pyogenes $(20 \mathrm{~mm})$ and the hexane extract $(12 \mathrm{~mm})$. Among all extracts of $S$. cayennensis and fractions, only the ethyl acetate fraction (EAF) from the ethanol extract, showed activity by agar diffusion method against the $B$. subtillis $(10 \mathrm{~mm}), S$. saprophyticus (11 $\mathrm{mm}), S$. epidermidis $(16 \mathrm{~mm}), S$. aureus $(15 \mathrm{~mm})$, and S. pyogenes $(25 \mathrm{~mm})$. Butanol fraction showed activity only against the $S$. aureus $(10 \mathrm{~mm})$ and $S$. pyogenes $(22 \mathrm{~mm})$. The DPPH $\bullet$ antioxidant and antimicrobial activities of butanol fraction could be connected to the presence of the same arylpropanoid glycosides isolated from the EAF fraction, as noted in the chromatographic profile (De Souza 2004). Thus, the EAF fraction was subjected to a chromatographic purification by highspeed countercurrent chromatography (HSCCC) to give the verbascoside, isoverbascoside and martynoside. However, only the two major arylpropanoid glycosides verbascoside and martynoside were subject of antimicrobial assays. The combinations of phenols compounds often exert additive or positive synergistic action against the growth of microorganisms (Aliotta et al., 1992; Williamson, 2001). In this respect, we believe that the mixture of verbascoside, martynoside and isoverbascoside of the EAF fraction shows greater antibacterial inhibition when compared to other fractions of $S$. cayennensis. On the other hand, only the $S$. pyogenes was more sensitive to the EAF using the agar diffusion method and as minimum inhibitory concentrations (MIC) $(25 \mathrm{~mm} ; 80 \mu \mathrm{g} / \mathrm{mL})$. All to others fractions were not actives even at the highest concentration used by MIC $(1000 \mu \mathrm{g} / \mathrm{mL})$. Moderate antibacterial efficacies were shown by verbascoside (20 $\mathrm{mm} ; 62 \mu \mathrm{g} / \mathrm{mL}$ ) and martynoside (22 mm; $40 \mu \mathrm{g} / \mathrm{mL})$ against $S$. pyogenes. Martynoside was not tested to the others microorganisms. Moderate antibacterial activity against $S$. aureus was shown also by verbascoside $(13 \mathrm{~mm} ; 63 \mu \mathrm{g} / \mathrm{mL})$ and $S$. epidermidis $(20 \mathrm{~mm} ; 32$ $\mu \mathrm{g} / \mathrm{mL}$ ) and its observed antimicrobial activity is in agreement with literature data (Rigano et al., 2007). The antimicrobial results suggest that the arylpropanoid glycosides isolated may provide a useful application in medicine, because in certain immuno-compromised patients $S$. epidermidis, $S$. aureus and $S$. pyogenes can 
be a prominent source of morbidity and mortality. These microorganisms are the cause of many important human diseases from superficial skin infections (Bowden et al., 2002, Berner et al., 2000).

\section{In vivo and in vitro antioxidant assay of $S$ cayennensis}

All arylpropanoid glycoside compounds isolated from ethyl acetate fraction (EAF) showed outstanding DPPH• scavenger activities with antioxidant capacity (Table 1) when compared to the Ginkgo biloba extract and quercetin, which were used as standards due to their wellestablished antioxidant activity (Silva et al., 2009; Zhou $\&$ Sadik, 2008). Therefore, the DPPH• radical scavenging activity of the studied compounds and fractions may be attributed to the presence of phenolic hydroxyl group when compared to the chloroform fraction which does not contain such compounds. The antioxidant capacity of phenolic compounds, bearing two or four phenolic hydroxyl groups in the structure have been recognized to function both as electron and hydrogen donors (Van Acker et al., 1993). Thus, the number of phenolic hydroxyl groups may play an important role in their scavenging activity (Roginsky et al., 1996). The results from the DPPH experiments (Table 1) thus confirm that both $\mathrm{H} \bullet$ donating ability and the antioxidant activity are more pronounced in the verbascoside $(10.10 \pm 0.24)$ having the free phenolic $\mathrm{OH}$ groups compared to the martynoside. However, it is likely that the methoxy substitution may introduce steric hindrance, resulting in significant reduction in the rate constant with DPPH • radicals as observed in methoxylated compounds like martynoside $(23.33 \pm 2.50)$.

Table 1. Evaluation of the antioxidant capacity of Stachytarpheta cayennensis (Rich.) Vahl, Verbenaceae extracts and the isolated compounds against DPPH by radical scavenging activity was expressed as IC50 $\left(\mathrm{R}^{2} \geq 0.97\right)$ and compared to standard Ginkgo biloba extract and quercetin. All fractions and isolated compounds from ethanolic extract, except for G. biloba (GBE) and quercetin (Q), as described in material and methods. Values are mean $\pm \mathrm{SD}$ of at least three independent experiments and statistically different $(p<0,05)$.

\begin{tabular}{|c|c|}
\hline $\begin{array}{l}\text { Extracts, fractions and isolated compounds from } \\
\text { S. caynnensis }\end{array}$ & $\operatorname{IC50}(\mu \mathrm{g} / \mathrm{mL})$ \\
\hline Ethanolic extract & $62.21 \pm 1.82$ \\
\hline Chloroform fraction & $59.51 \pm 1.81$ \\
\hline Ethyl acetate fraction & $15.16 \pm 0.72$ \\
\hline Butanolic fraction & $34.84 \pm 2.25$ \\
\hline Verbascoside & $10.10 \pm 0.24$ \\
\hline Isoverbascoside & $11.40 \pm 1.13$ \\
\hline Martynoside & $23.33 \pm 2.50$ \\
\hline G. biloba extract & $26.60 \pm 0.00$ \\
\hline Quercetin & $65.00 \pm 0.00$ \\
\hline
\end{tabular}

Characterizing antioxidant solely on the basis of ability to scavenge free radicals is inadequate. Thus, we also evaluated the antioxidant activity of $S$. cayennensis extract, fractions and our two major isolated compounds, verbascoside and betulinic acid, using the yeast $S$. cerevisiae. S. cerevisiae was chosen as a model due to the availability of the complete genomic sequence and the apparent similarity of the defense mechanisms in yeast and human cells (Foury 1997).

$S$. cereviseae cells growing exponentially on glucose are very sensitive to an oxidative stress, because under these conditions they only ferment and do not oxidize glucose (Pereira et al., 2003). However, the use of antioxidants can help protect against oxidative stress, increasing cellular tolerance (Dai et al., 2006). We tested different methods of stimulating oxidative stress: by use of hydrogen peroxide $\left(\mathrm{H}_{2} \mathrm{O}_{2}\right)$ or menadione. Both menadione and $\mathrm{H}_{2} \mathrm{O}_{2}$ can generate the hydroxyl radical (HO•), the most toxic reactive oxygen species (ROS) (Roginsky et al., 1996; Belinha et al., 2007). Menadione can also cause an oxidative stress by forming a complex with glutathione, the main antioxidant thiol (Steels et al., 1994).

According to Figure 1A, the crude ethanol in extract (CEE), ethyl acetate fraction (EAF) and chloroform fraction (CF) fractions of S. cayennensis resulted in a 2-fold increase in the cellular survival against oxidative stress by superoxide $\left(\mathrm{O}_{2}^{-}\right)$induced by menadione. The celular survival was comparable to the increase observed when the cells were treated with $G$. biloba extract. Verbascoside presented a 7-fold increase of cellular viability in comparison to the cells stressed by menadione, while betulinic acid showed an 11-fold increase in cell viability. Both results are more significant than the ones presented by the quercetin standard (Figure 1A). When hydrogen peroxide $\left(\mathrm{H}_{2} \mathrm{O}_{2}\right)$ was used as inductor of oxidative stress, it was observed that the extracts and fractions of $S$. cayennensis showed similar increases of cellular survival to the one verified in the stress induced by menadione. Verbascoside exhibited a 9-fold increase of cellular viability, while betulinic acid showed a similar effect compared to the standard compound quercetin (4-fold) (Figure 1B). It is generally considered that the peroxidation inhibition of an antioxidant may be due to the free radical scavenging activity. The CEE and the EAF samples reduced lipid peroxidation levels in the menadione induced stress (Figure 2A). This reduction can be related to the increase of cellular survival observed in treatment with those samples, according to Figure 1A. The CF remained at the same levels as those of the no treated cells, indicating that its mechanism to increase the antioxidant activity through cellular tolerance is not motivated by the lipid peroxidation levels decrease (Figure 2A). Betulinic acid isolated from the CF fraction was able to decrease the lipid peroxidation to similar levels as those of verbascoside. These results suggest 
that the increase of cellular survival observed with both isolated compounds can be related to the reduction of lipid peroxidation in the stress by menadione (Figures $1 \mathrm{~A}$ and 2A). On the other hand, betulinic acid presented an increase of cellular viability greater than the one presented by verbascoside, which may indicate that other modes of action may be involved.
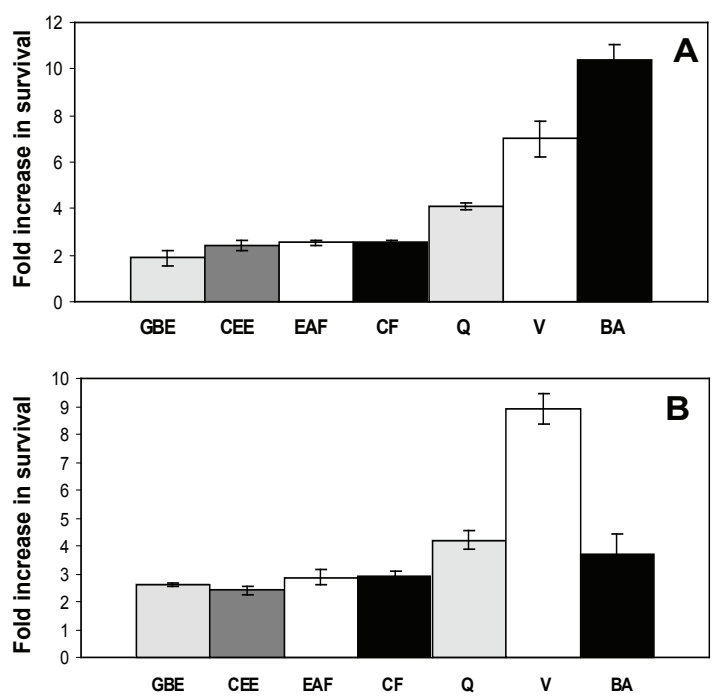

Figure 1. Effect of plant extracts and isolated compounds on cell viability after stress with $20 \mathrm{mM}$ menadione (A) and 2 $\mathrm{mM}$ hydrogen peroxide (B). GBE: Ginkgo biloba; CEE: crude ethanol extract; EAF: ethyl acetate fraction; $\mathrm{CF}$ : chloroform fraction; Q: quercetin; V: verbascoside; BA: betulinic acid. Values are mean $\pm \mathrm{SD}$ of at least three independent experiments and statistically different (treated cells vs. non-treated cells; $p<0.05)$.

According to Figure 2B, the EAF fraction showed an improved decrease of the lipid peroxidation levels in the stress induced by $\mathrm{H}_{2} \mathrm{O}_{2}$ in comparison with the $\mathrm{CEE}$ extract and $\mathrm{CF}$ fraction. This reduction associated to the increase of cellular viability (Figure 1B) may indicate possible positive synergistic effects caused by other arylpropanoid glycosides isolated from this fraction (Williamson, 2001). The results obtained from the present study confirmed the significant antioxidant effect of verbascoside and of betulinic acid from $S$. cayennensis using an in vivo assay, suggesting that the roots of this plant is a potential source of antioxidants.

In conclusion, the coexisting presence in $S$. cayennensis of anti-inflammatory, anti-ulcerogenic (Penido et al., 2004), antinociceptive (Schapoval et al., 1998), leishmanicidal (Moreira et al., 2007), antibacterial and antioxidant properties, without phototoxicity, suggest that this plant may provide a useful co-adjuvant strategy for use in folk medicine. Betulinic acid was first identified at the Stachytarpheta genus.
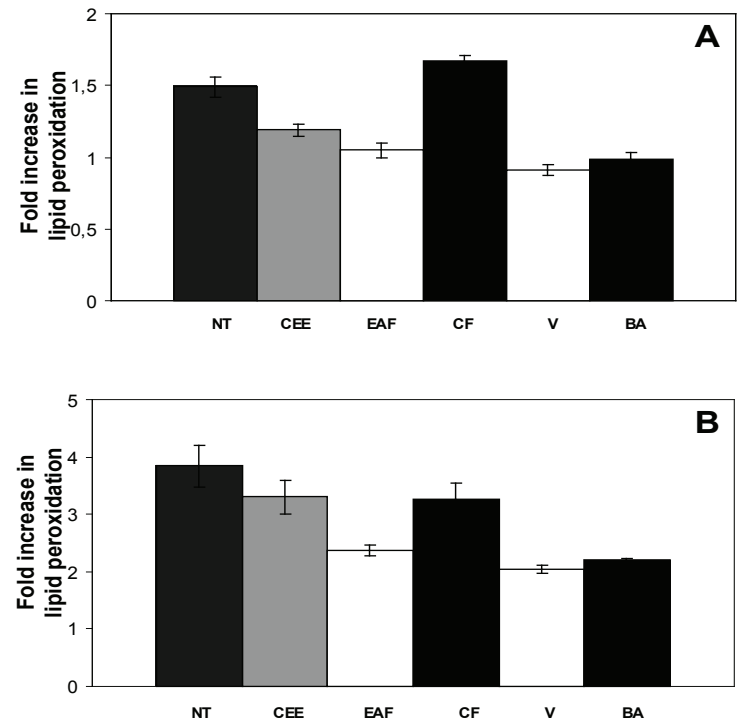

Figure 2. Effect of plant extracts and isolated compounds on lipid peroxidation after stress with $20 \mathrm{mM}$ menadione (A) and $2 \mathrm{mM}$ hydrogen peroxide (B). NT: not treated; GB: Ginkgo biloba; CEE: crude ethanol extract; EAF: ethyl acetate fraction; $\mathrm{CF}$ : chloroform fraction; Q: quercetin; V: verbascoside; BA: betulinic acid. Values are mean $\pm \mathrm{SD}$ of at least three independent experiments and statistically different (treated cells vs. nontreated cells; $p<0.05)$.

\section{ACKNOWLEDGEMENTS}

The authors are indebted to FAPERJ and CNPq for financial support and to Dra. Inês M. Oliveira (UFRuralRJ) for her help in identifying the voucher specimen.

\section{REFERENCES}

Aliotta G, Molinaro A, Monaco P, Pinto G, Previtera L 1992. Three biologically phenylpropanoid glucosides from Myriophyllum verticillatum. Phytochemistry 31: 109111.

Amaral S, Mira L, Nogueira JMF, da Silva AP, Helena Florencio $\mathrm{MH}$ 2009. Plant extracts with anti-inflammatory properties- A new approach for characterization of their bioactive compounds and establishment of structureantioxidant activity relationships. Bioorg Med Chem 17: 1876-1883.

Avila Acevedo JG, Castañeda CMC, Benitez FJC, Durán DA, Barroso V R, Martínez CG, Muñoz LJL, Martínez CA, Romo de Vivar A 2005. Photoprotective activity of Buddleja scordioides. Fitoterapia 76: 301-309.

Belinha I, Amorim MA, Rodrigues P, De Freitas V, MoradasFerreira P, Mateus N, Costa V 2007. Quercetin increases oxidative stress resistance and longevity in $S$. cerevisiae. $J$ Agric Food Chem 55: 2446-2451.

Berner R, Herdeg S, Gordjani N, Brandis M 2000. Streptococcus pyogenes meningitis: report of a case and review of the 
literature. Eur J Pediatr 159: 527-529.

Bowden MG, Visai L, Longshaw CM, Holland KT, Speziale P, Höök M 2002. Is the GehD lipase from Staphylococcus epidermidis a collagen binding adhesin? J Biol Chem 277: 43017-43023.

Dai F, Miao Q, Zhou B, Yang L, Liu ZL 2006. Protective effects of flavonols and their glycosides against free radicalinduced oxidative hemolysis of red blood cells. Life Sci 78: 2488-2493.

De Souza PA 2004. Estudo fitoquimico e farmacologico P. bahienenis e $\mathrm{S}$.cayennensis. Rio de Janeiro, 139p. Dissertação de Mestrado, Programa de Pós-graduação em Química Orgânica, Universidade Federal Rural do Rio de Janeiro.

Didry N, Seidel V, Dubreuil L, Tillequin F, Bailleul F 1999. Isolation and antibacterial activity of phenylpropanoid derivatives from Ballota nigra. J Ethnopharmacol 67: 197-202.

Ellen BJ, Lance RP, Sydney MF 1994. Diagnostic Microbiology ( $9^{\text {th }}$ ed.). Mosby (ed.)

Foury F 1997. Human genetic diseases:a cross-talk betweewn man and yeast. Gene 195: 1-10.

Freitas ZMF, Machado PA, Dellamora-Ortiz GM, Santos EP, Gonçalves JCS 2000. Evaluation of phototoxicity of the sunscreens: 1,2,3-propanetriol 1,3-dipalmitoyl2-p-methoxycinnamoyl and 1,2,3-propanetriol 1,3dioctanoyl-2-p-methoxycinnamoyl. STP Pharma Sciences 10: 239-242.

Jimenez C, Riguera R 1994. Phenylethanoid glycosides in plants: structure and biological activity. Nat Prod Rep 11: 591606.

Leitão GG, De Souza PA, Brow L, Moraes AA 2005. Stepgradient CCC separation of phenylpropanoid and iridoid glycosides from roots of Stachytarpheta cayennesis (Rich.) Vahl. J Liq Chromatogr Relat Technol 28: 20532060.

Mahato BS 1994. 13C NMR Spectra of pentacyclic triterpenoids - a compilation and some salient features. Phytochemistry 37: 1517-1575.

Montoya NCS, Comini LR, Sarmiento M, Becerra C, Albesa I, Argüello GA, Cabrera JL 2005. Natural anthraquinones probed as Type I and Type II photosensitizers: singlet oxygen and superoxide anion production. $J$ Photochem Photobiol Biol B 78: 77-83.

Moreira CRR, Costa CG, Lopes TC, Bezerra JT, Guerra RNM, Rebêlo JMM, Ribeiro MNS, Nascimento FRF, Costa JML 2007. Efeito leishmanicida in vitro de Stachytarpheta cayennensis (Rich.)Vahl (Verbenaceae). Rev Bras Farmacogn 17: 59-63

Mothana RAA, Lindequist U 2005. Antimicrobial activity of some medicinal plants of the island Soqotra. J Ethnopharmacol 96: 177-181.

Parejo I, Viladomat F, Bastida J, Rosas-Romero A, Saavedra G, Murcia MA, Jiménez AM, Codina C 2003. Investigation of Bolivian plant extracts for their radical scavenging activity and antioxidant activity. Life Sci. 73: 16671681.

Penido C, Costa KA, Futuro DO, Paiva SR, Kaplan MAC, Figueiredo MR, Henriques MGMO 2006. Antiinflammatory and anti-ulcerogenic properties of Stachytarpheta cayennensis (L.C. Rich) Vahl. J Ethnopharmacol 104: 225-233.
Pereira MD, Herdeiro RS, Fernandes PN, Eleutherio ECA, Panek AD 2003. Targets of oxidative stress in yeast sod mutants. Biochim Biophys Acta 1620: 245-251.

Prior LR 2004. Plasma antioxidant measurements. J Nutr 134: 3184S-3185S.

Ramos MFS, Santos EP, Silva AB, Leitao AC, Dellamora-Ortiz GM 2005. Avaliação fototóxica e screening mutagênico de extratos de própolis, Aloe spp. e Hamamelis virginiana. Rev Cienc Farm Basica Apl 2: 105-111.

Rigano D, Formisano C, Basile A, Lavitola A, Senatore F, Rosselli S, Bruno M 2007. Antibacterial activity of flavonoids and phenylpropanoids from Marrubium globosum ssp Libanoticum. Phytother Res 21: 395-397

Roginsky VA, Barsukova TK, Remorova AA 1996. Moderate antioxidative efficiencies of flavonoids during peroxidation of methyl linoleate in homogenous and micellar solutions. J Am Oil Chem Soc 73: 777-786.

Schapoval EES, Winter de Vargas MR, Chaves CG, Bridi R, Zuanazzi JA, Henriques AT 1998. Antiinflammatory and antinociceptive activities of extracts and isolated compounds from Stachytarpheta cayennensis. J Ethnopharmacol 60: 53-59.

Schoenknecht FD, Sabath LD, Thornsberry C 1985. Manual of Clinical Microbiology. Washington DC: American Society for Microbiology.

Silva CG, Raulino RJ, Cerqueira DM, Mannarino SC, Pereira MD, Panek AD, Silva JFM, Menezes FS, Eleutherio ECA 2009. In vitro and in vivo determination of antioxidant activity and mode of action of isoquercitrin and Hyptis fasciculata. Phytomedicine 16: 761-767.

Steels EL, Learmonth RP, Watson K 1994. Stress tolerance and membrane lipid insaturation in Saccharomyces cerevisiae grown aerobically or anaerobically. Microbiology 140: 569-576.

Van Acker SA, Koymans LM, Bast A 1993. Molecular pharmacology of vitamin E: structural aspects of antioxidant activity. Free Rad Biol Med 15: 311-328.

Wilhelm KP, Biel S, Siegers CP 2001. Role of flavonoids in controlling the phototoxicity of Hypericum perforatum extracts. Phytomedicine 8: 306-309.

Williamson ME 2001. Synergy and other interactions in phytomedicines. Phytomedicine 8: 401-409.

Zhou A, Sadik AO 2008. Comparative analysis of quercetin oxidation by electrochemical, enzymatic, autoxidation, and free radical generation techniques: a mechanistic study. J Agric Food Chem 56: 12081-12091. 